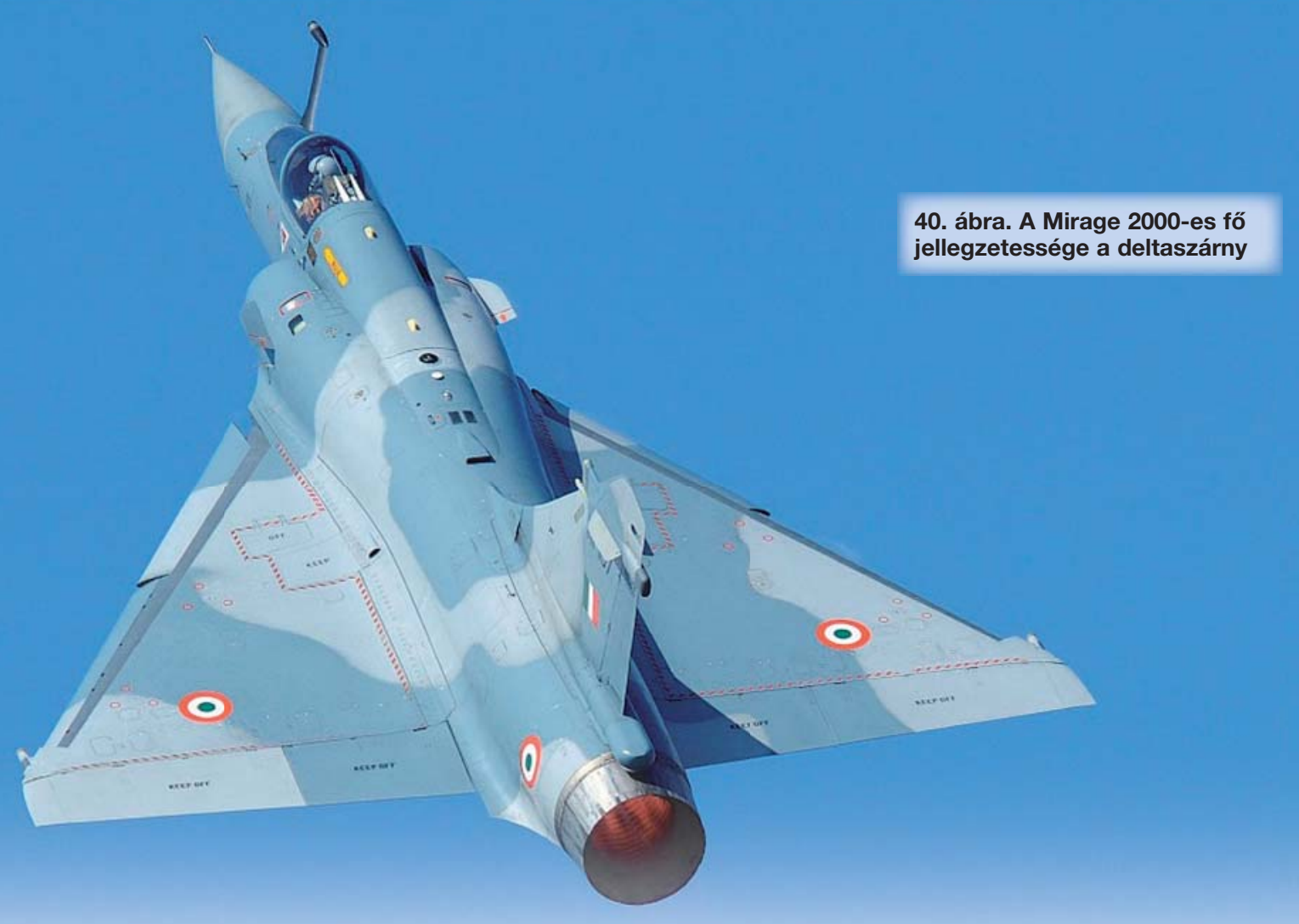

Kelecsényi István

\title{
Harminc éves az utolsó deltaszárnyú, a Dassault Mirage 2000 wrresz
}

\section{HarCI ALKALMAZÁSOK}

A Mirage 2000 repülőgépek harci alkalmazása a második öbölháborúban kezdődött, amikor az orange-i 5. repülőszázad Chasseur gépei 1416 órát repülve, 508 légvédelmi bevetésen vettek részt. Légi győzelmet nem arattak, veszteségük sem volt. A század 1998-ig vett részt Irak légterének ellenőrzésében, utána hazarendelték őket. Az Egyesült Arab Emirátusok 2000ED vadászai is légvédelmi repüléseket végeztek a háború alatt, de közvetlen harcérintkezésbe - akárcsak a franciák - nem kerültek.

1993-ban az orange-i alakulat vadászai részt vettek a Bosznia feletti hadműveletekben. A bevetéseket Olaszországból, a cerviai és az istranai bázisokról repülték. 1995ben hagyományos fegyverzettel bevetették a Mirage $2000 \mathrm{~N}$ atombombázókat is. Az Mk82-es bombákkal támadó gépek közül egyet a szerbek 9K310 Igla I. (SA-16-os) kézi légvédelmi rakétával lelőttek. A hajózók, Frederick Chifott százados és Jose Sauvignet hadnagy katapultáltak és fogságba estek.

Az 1999-es kasmíri konfliktusban az indiai légierő rendszeresen támadta a gerillák állásait hagyományos szabadesésű és lézervezérlésủ bombákkal. A Gwaliorban állomásozó 1. Tigers (Tigris) és 7. Battleaxe (Csatabárd) századok Mirage $2000 \mathrm{H}$ (VARJA) gépei az amerikai Paveway II és a francia BGL1000 lézerbombákat ATLIS célzókonténerekkel vezették célra. Az első csapásra június 17-én került sor, ekkor még 450 kg-os, nem irányított bombákkal. Június 24-én a Tiger Top hegyen álló pakisztáni állásra történt az első GBU-12-es kioldása. Az ezt követő napokban a század éjjel-nappal támadta az ellenséget. Az éjszakai támadásokat hagyományos bombákkal hajtották végre, mert az ATLIS nem rendelkezik éjszakai üzemmóddal. Csapásmérésre a 7 . század négygépes köteléke jellemzően 12 darab bombával és a külső pilonokon és MATRA Magic légiharcrakétával repült. Az 1. Tigrisek három Mirage 2000 gépe vadászkonfigurációban MATRA Super530D közép hatótávolságú és Magic légiharcrakétákkal a fedezetet biztosította. A kötelékek magassági oltalmát MiG-29-es géppárok végezték. A támadásokat $10 \mathrm{~km}$ magasságból zuhanásban oldott, nem irányított bombákat hordozó Délibábokkal indították, majd a mögöttük érkező Mirage 2000TH vadászbombázó felmérte az okozott károkat ATLIS célzókonténerrel, és szükség esetén a megmaradt célokat lézerirányítású bombával támadta. A konfliktus során összesen nyolc lézerbombát használtak fel Mirage 2000-ressel. Június 8-án indiai adatok szerint egy négygépes Deux-Mille kötelék 24 darab 450 kg-os hagyományos bombával teljesen megsemmisített egy pakisztáni katonai tábort. A háború elején pakisztáni $\mathrm{F}-16$-os gépekkel került a francia típus harcérintkezésbe, de rakétaindításra nem került sor. Az indiai századok a konfliktus során 515 alkalommal emelkedtek a levegőbe, ebből 240 bombázó bevetés volt. A gépek karbantartásával és hadrafoghatóságával is elégedett volt az indiai hadvezetés.

2002-ben kirgizisztáni Manasz repülőterére 6 darab Mirage 2000D vadászbombázót telepített a francia légierő, hogy felderítő és CAS közeltámogató bevetésekben ve- 


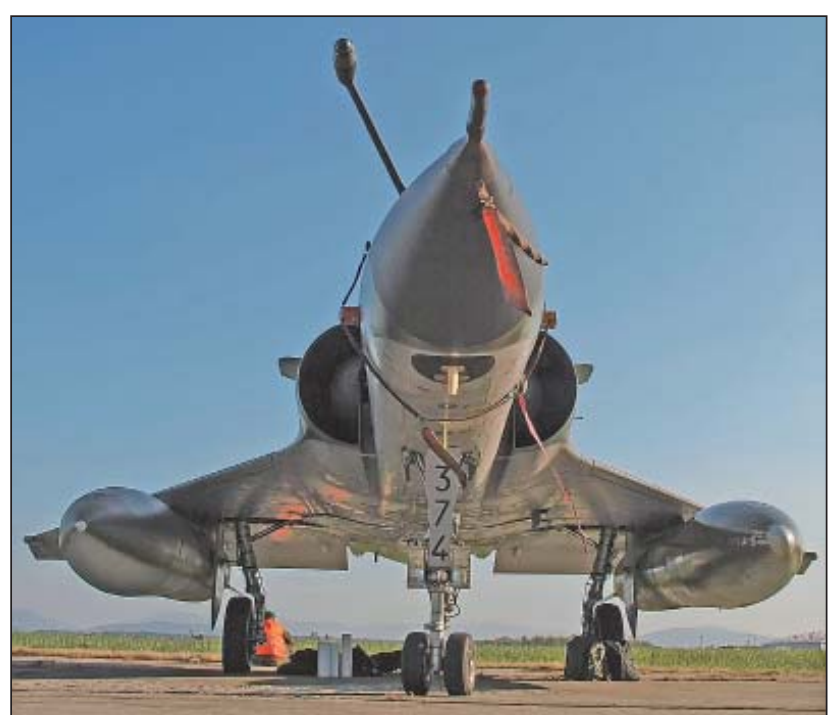

41. ábra. Mirage $2000 \mathrm{~N}$ változat póttartályokkal. Franciaországban a Diversifie és Nucléaire csapásmérő változatokkal történt a legtöbb baleset, elsősorban a sok alacsony repülési profil miatt

gyenek részt Afganisztán felett. Később Manaszból a tadzsik Dushanbe és az afganisztáni Kandaharban lévő támaszpontokat használták a franciák. A szárazföldi csapatok támogatására, és a tálibok ellen Franciaország az afganisztáni hadszíntéren 3-6 darab Mirage 2000D-t állomásoztat folyamatosan. A 2001. szeptember 11-i terrortámadás után hónapokig egyszerre több francia repülőbázison 10 darab Mirage 2000 állt kétperces készenlétben. A kétperces készenlét annyit jelent, hogy a pilóták a gépekben ülve várták a parancsot, és a „Délibábok” töltött gépágyúval repülték a gyakorló repüléseket is. (A Magyar MiG-29es vadászrepülőgépek minden gyakorló bevetésre töltött éles gépágyúval repültek.)

1995-ben a perui Mirage 2000 vadászbombázók is az Ecuador elleni háborúban a harci térségben települtek. Kevés bevetést repültek, mivel alkatrészhiány miatt alig 3-4 darab francia vadászbombázójuk volt üzemképes. A háború során az orosz gyártmányú MiG-29-es vadászokkal és Szuhoj Szu-20M harci repülőgépekkel repültek. 1995. február 10-én az ecuadori Mirage F1 vadászbombázok lelőttek két perui Szuhoj Szu-20M csapásmérőt. A készültségben álló Deux-Mille repülőgépeket a levegőbe emelték,

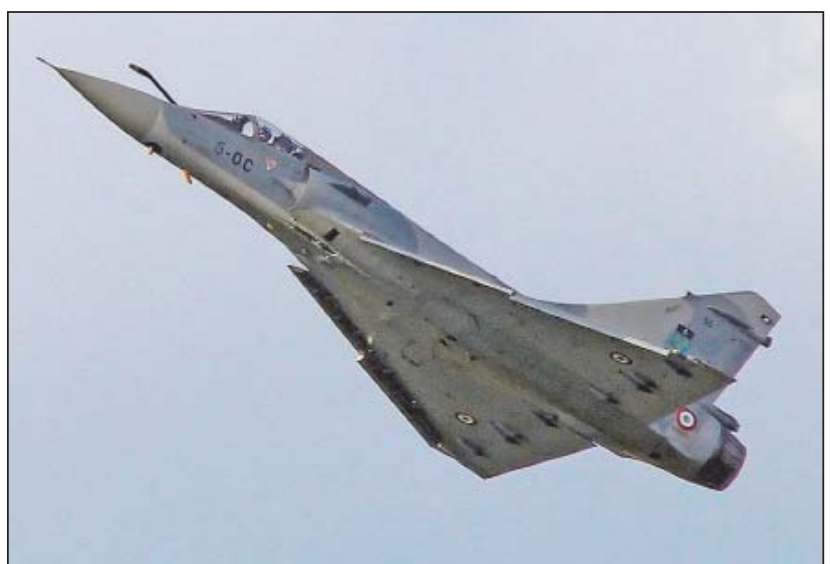

43. ábra. Nagy állásszögű bemutatórepülés közben a francia légierő Cigognes ezredének Mirage 2000-5F vadászrepülőgépe

a Mirage F1-es gépeket elfogták, azonban közép hatótávolságú Super530-as rakétákat a peruiak nem rendszeresítették, a Magic kis hatótávolságú közelharcrakétákkal pedig nem sikerült indítási távolságba kerülni.

A görögök gépei is végrehajtottak éles bevetéseket. Az Égei-tenger felett a második világháború óta folyó törökgörög konfliktus során sok fegyverhasználat nélküli légiharcot vívtak a két NATO tagország gépei. Ebben részt vettek a hellén Mirage 2000 harci repülőgépek is. 1996. október 8-án a tanagrai támaszpontról a 331. század Mirage 2000-es gépeit riasztották a görögök szerint légterükbe behatoló török F-4E Phantom II. vadászbombázók ellen. A felek fegyverhasználat nélküli manőverező légiharcába bekapcsolódtak török F-16-os vadászbombázók is, amelyek a körzetben függesztmény nélkül, töltött gépágyúkkal végeztek gyakorló repülést. Thanos Gavras hadnagy Mirage 2000 repülőgépéről egy Magic II közelharcrakétát indított a 91-0023-as szériaszámú török kétüléses $\mathrm{F}-16 \mathrm{D}$ vadászbombázóra. A rakéta eltalálta a Falcont, és annak első ülésében Nail Erdogan százados azonnal életét vesztette. Társa Cemil Cicekli alezredes katapultált és fél óra múlva a görög kutató-mentő szolgálat kimentette a tengerből. A vizsgálat megállapította, hogy a botkormányon tévesen éles helyzetben volt a fegyverzeti kapcsoló, és a pilóta véletlenül indította el rakétát. A görög pilótát letiltották a további repülésekről. Eddig ez volt a Mirage 2000-es egyetlen légigyőzelme.

42. ábra. Egy Tigris emelkedik el a betonról a 2011. évi Tiger Meet gyakorlaton, Cambrai-Epinoy-ban. A francia légierőnél nagy hagyománya van a díszfestésnek

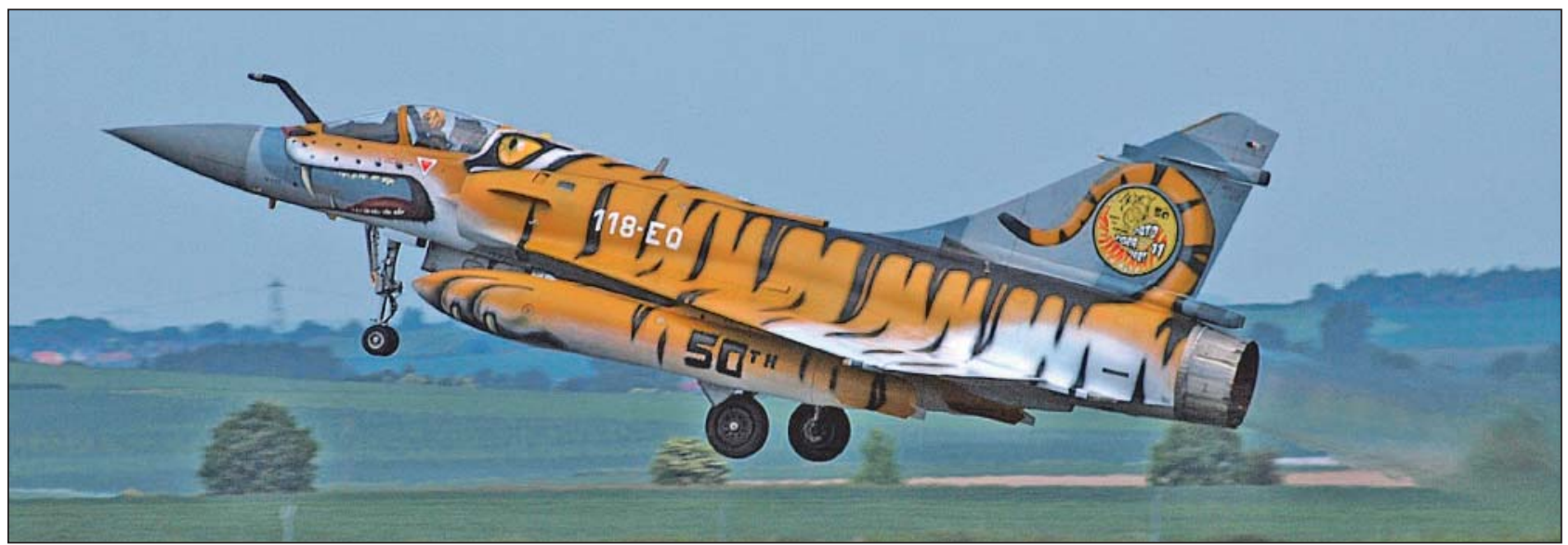




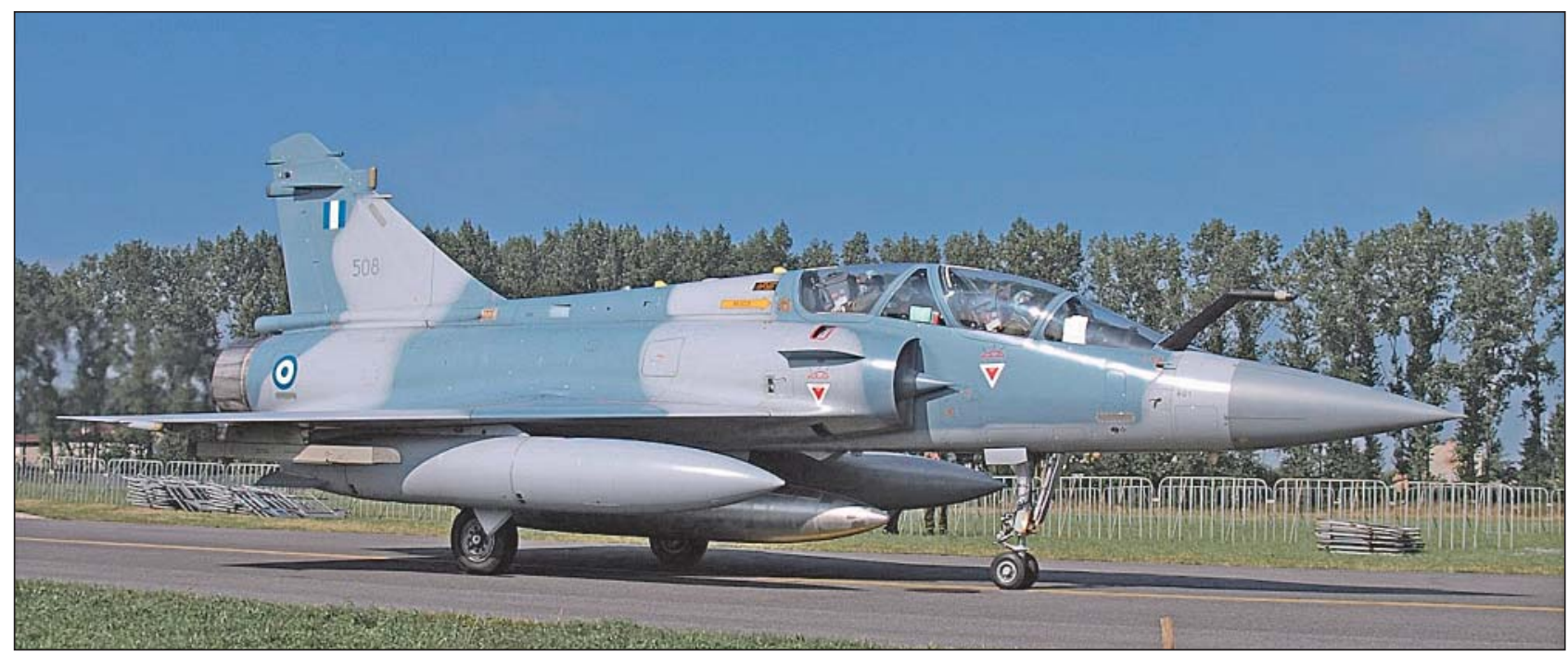

\section{4. ábra. A görög légierő Mirage 2000-es harci repülőgépe}

Franciaország, Katar és az Egyesült Arab Emirátusok (Abu Dhabi) gépei 2011-ben részt vettek a líbiai konfliktusban. Az első légicsapásokat 2011. március 19-én indította a francia légierő. Az Operation Harmattan hadművelet első napján 8 darab Rafale $C$ vadászbombázó, 2 darab Mirage 2000-5F vadász, 2 darab Mirage 2000D csapásmérő, 6 darab C-135FR légi utántöltő és egy darab E3F AWACS légtérellenőrző repülőgép bevetésével elsősorban Benghazi környékén biztosították a repüléstilalmi zónát és mértek csapást Kadhafi erőinek légvédelmi rendszerére, valamint nehézfegyverzetére. A franciák először vetették be éles helyzetben az amerikai gyártmányú GBU-12-es lézerirányítású, valamint francia gyártású az amerikai bombáknál jobban manőverező, kombinált lézer és GPS irányítású AASM bombákat. Az első támadások után újabb francia repülőkötelékeket vetettek be, köztük Csádból Mirage F1-es vadászbombázó és Mirage 2000-5F vadászrepülőgépeket.

A Mirage 2000-5F gépekkel felszerelt az 1/2 Cigognes (Gólyák) az ENSZ által kijelölt repüléstilalmi zónát ellenő- rizték, valamint légifedezetet biztosítottak a támadógépeknek. A katariak a görögországi Souda Bay légitámaszpontról átelepített Mirage 2000-5-ös repülőszázadukat vetették be, az emirátusok hat-hat darab Mirage 2000-9-es és F-16 Block 60-as vadászbombázót biztosítottak a koalíció számára.

Az Egyesült Arab Emitárusok Mirage 2000-9-es vadászbombázóit a szicíliai Trappani repülőtérére telepítették, és onnan repülték bevetéseiket.

A francia légierő Nancy-ból indította a Mirage 2000D, Dijonból a Mirage 2000-5F repülőgépeket. A repülési távolság miatt, a franciak szinte minden KC-135F tankergépüket bevetették, de amerikai Mildenhall-i tankerekről is hajtottak végre légi utántöltést. A hadművelet során bebizonyosdott, hogy a régebbi Mirage 2000D-k korlátozott támadókapacitással rendelkeznek, mivel két-három póttartály mellett a fegyverterhelésük néhány bombából állt. A korszerűbb, Mirage 2000-5-ös és 2000-9-es vadászbombázók fegyverterhelése egyenrangú volt a Das-

\section{5. ábra. A brazil Mirage 2000-es vadászrepülőgép}

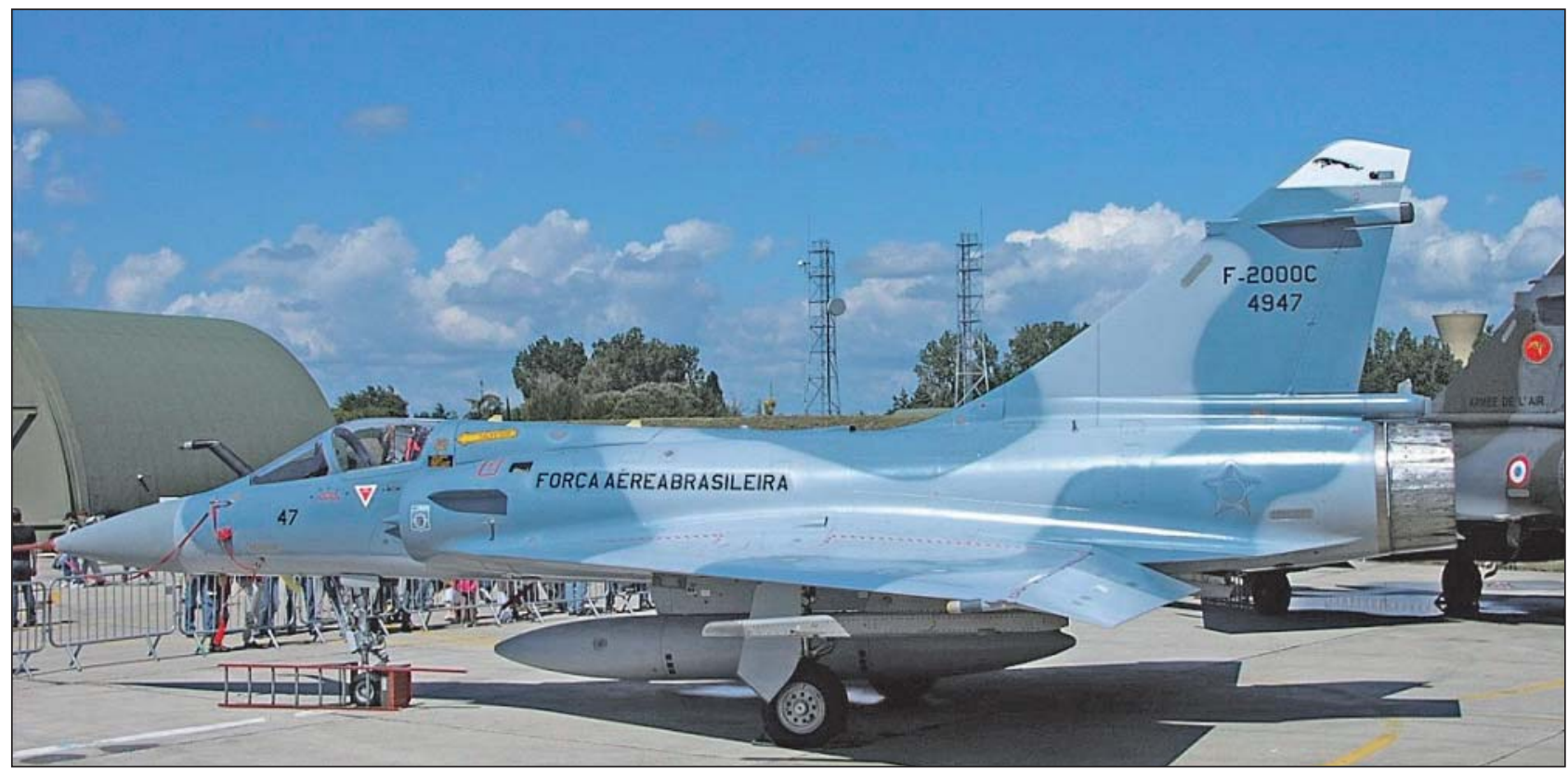




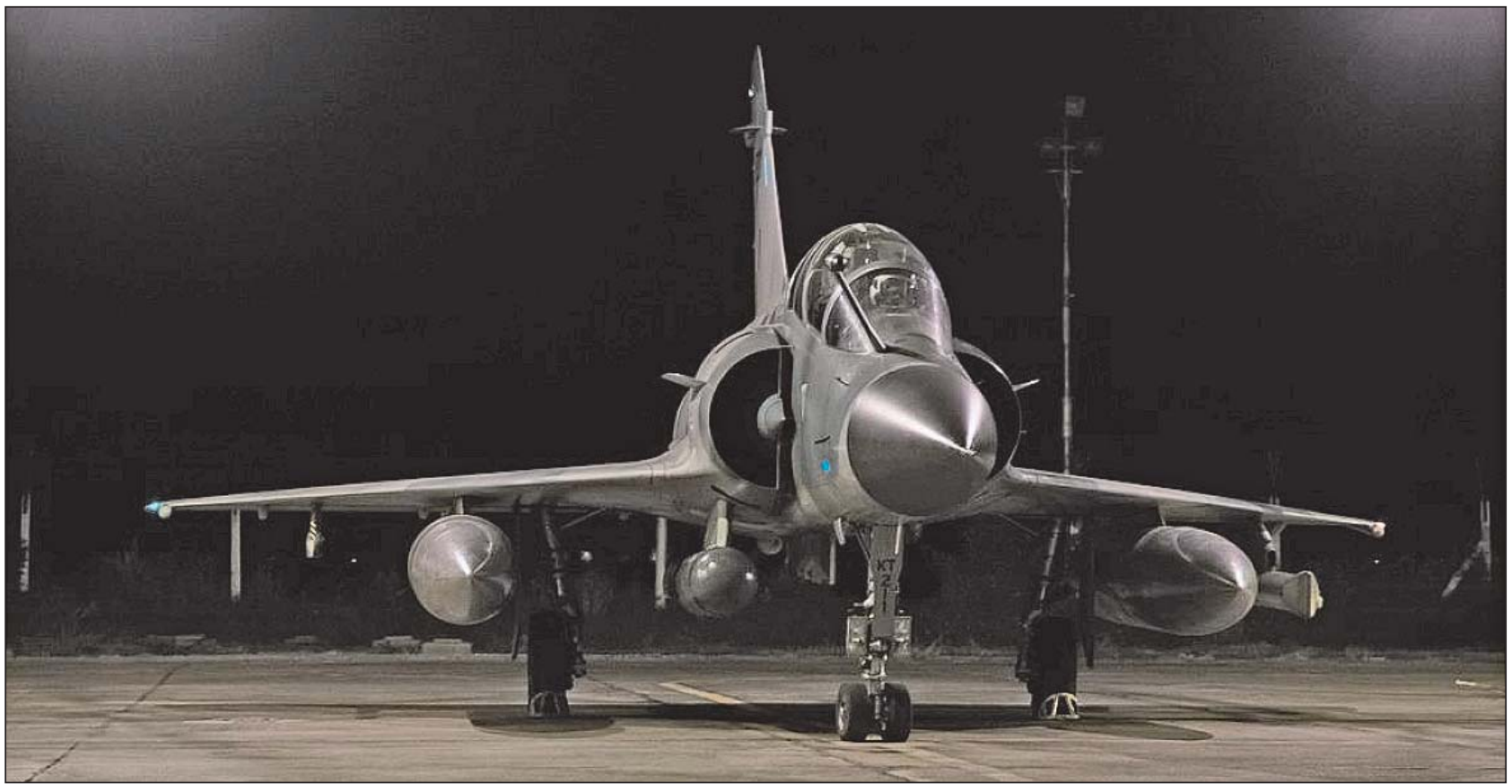

46. ábra. A brazil légierő Mirage 2000-es harci repülőgépe szárny alatti póttartályokkal

sault Rafale és a koalíciós erők más támadógépeinek kapacitásával.

A baltikumi légirendészeti feladatokban a Deux-Mille is bevetésre került. Először 2007. április 1-től a colmari chasseur egység volt négy hónapig Litvániában, majd 2010. január 4-től a Cambrai-Épinoyban állomásozó 109. és 122. escadrille egy-egy géppárja teljesített szolgálatot. 2011. április 28-tól ismét a cambari alakulat és az OrangeCaritat bázisról a 94. és 99. escadrille géppárjai adtak QRA készültséget a siauliai repülőtéren. 2011. augusztus 11-én az egyik francia vadász összeütközött a levegőben a litván légierő L-39ZA Albatros kiképzőgépével. A litván pilóták katapultáltak, a Mirage 2000 sikeres kényszerleszállást hajtott végre. 2014. április 28. és május 1. között, a francia légierő Rafale és Mirage 2000-es vegyes harccsoportja biztosította a balti államok légterének védelmét. Az oroszukrán konfliktus miatt 12 gépesre növelt egység, a közelharc rakéták mellett $B V R$ látóhatáron túli légiharcrakétákkal adta a készültséget, illetve őrjáratozott.

2014. augusztusban az Abu Dhabi Mirage-ok Líbiában és Egyiptomban is bombázták a terrorszervezetek támaszpontjait és kiképzőtáborait.

2014 nyarán a francia kormány hat darab Mirage 2000D csapásmérőt telepített a nigériai Niamey repülőterére, hogy támogassák a Maliban lévő francia erők kormányellens felkelőkkel szembeni tevékenységét. Június 9-én az egyik éjszakai felderítésen résztvevő Duex-Mille műszaki hiba miatt visszafordult Nigéria légterébe és ott lezuhant. A két hajózó katapultált, a kutató-mentő egység megtalálta és a bázisra szállította őket.

A Mirage 2000 vadászombázók napjainkban is éles bevetéseket hajtanak végre. A 2015. november 13-i, Párizsban elkövetett terrortámadások után Mirage 2000, Rafale vadászbombázókat, valamint a Charles de Gaulle hordozó harcsoportot - fedélzetén Rafele és SEM vadászbombázókkal - vezényelték a közel-kelet térségébe.

A franciák elsősorban a Dassault Rafale vadászbombázókkal repülnek, mivel azok harcértéke nagyobb, valamint marketing szempontból is jobban eladható, ha minél több éles bevetésen részt vesz a Deux-Mille felváltására kifej- lesztett típus, de általában 4-6 Mirage-ból álló kötelékeket is diszlokálnak a Közel-Keletre, az ISIS elleni támadásokra.

A katari és az emirátusok gépei egyaránt az ISIS terrorszervezet ellen harcoló koalíciós erőket támogatják Szíria és Irak térségében indított csapásokkal.

2015. november 25-én nagyobb konfliktus alakult ki a görög és török légierő repülőgépei között, az Égei-tenger felett, Kosz sziget környékén a szokásos felségterületi viták miatt. Mindkét fél szerint a másik sértette meg a légteret. A török oldalon F-16-os, görök oldalon F-16-os és Mirage 2000G repülőgépek vettek részt a csetepatéban, ahol fegyverhasználatra nem kerül sor a manőverző légiharcok során. A görög Mirage-ok meg nem erősített hírek szerint meglepetésszerűen jelentek meg erősítésként a két ország F-16-osainak kergetőzésében, és kiváló pozícióban több légigyőzelmet is elérhettek volna. Az incidenes előtt 2015. június 16-án a görögök szerint 6 darab török F-16-os sértette meg 20 percre a hellének légterét.

47. ábra. A francia légierö Cigognes ezredének Mirage 2005F vadászrepülögépe a 2011. évi Tigris találkozón, a CambraiEpinoy repülöbázison. A két póttartályon kívül mást nem hordoz, a többi pilonja leszerelve

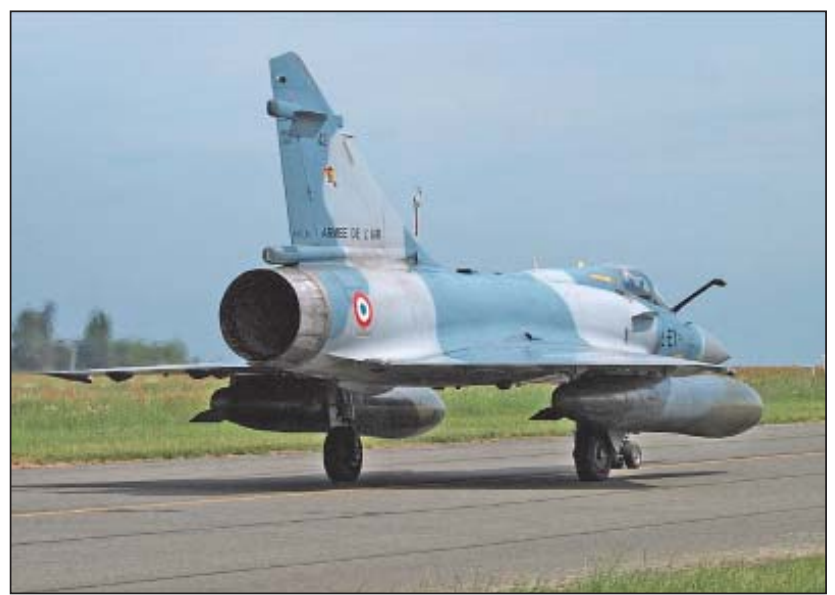




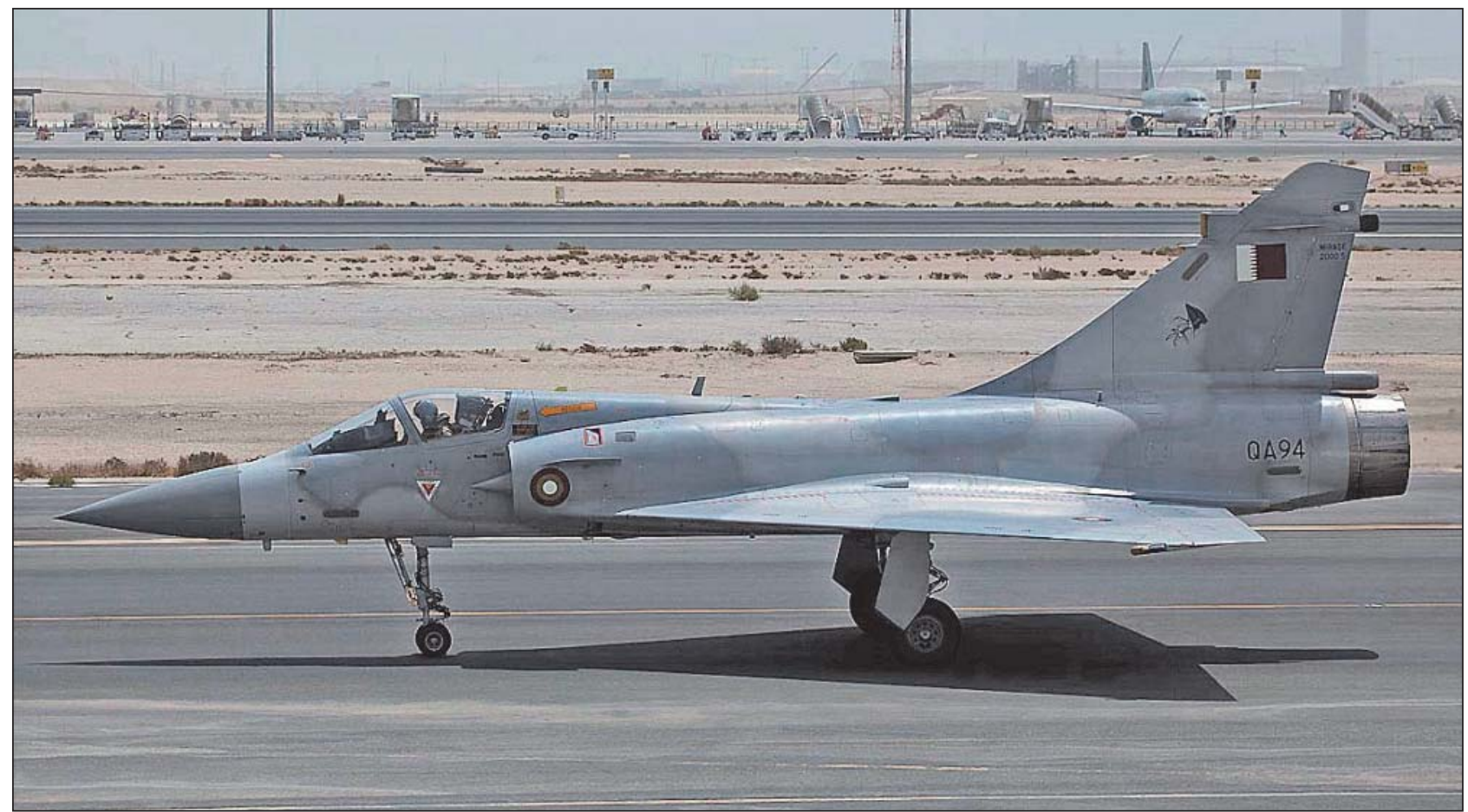

\section{8. ábra. A katari légierő Mirage 2000-es harci repülőgépei 2011-ben részt vettek a líbiai konfliktus kezelésében}

\section{VeSZTESÉGEK}

A Mirage 2000-es típuscsaládot alapvetően biztonságos repülőgépnek tekintik az üzemeltetők. Ennek ellenére, a statisztikai adatok szerint Franciaország és India repülőállományának 18\%-át balesetben vesztette el. Franciaországban a Diversifie és Nucléaire csapásmérő változatokkal történt a legtöbb baleset, elsősorban a sok alacsony repülési profil miatt. A korai Chasseur változatoknak az első időkben szintén rossz statisztikai mutatói voltak. Az indiai Deux-Mille repülőgépek a helyi viszonyok között, még ilyen statisztika mellett is a jó baleseti mutatókkal rendelkező géptípusok között vannak. Görögország 27,3\%-os békebeli veszteségét árnyalja, hogy 2004. szeptember 1-én egyszerre három vadászbombázót is elvesztettek manőverező légiharc-gyakorlat során. 2006-ban és 2007-ben egy-egy gépet vesztett a tanagrai ezred, azóta nem történt gépvesztés.

\section{9. ábra. Tajvan légierejének Dassault Mirage 2000-5-ös harci repülögépe}

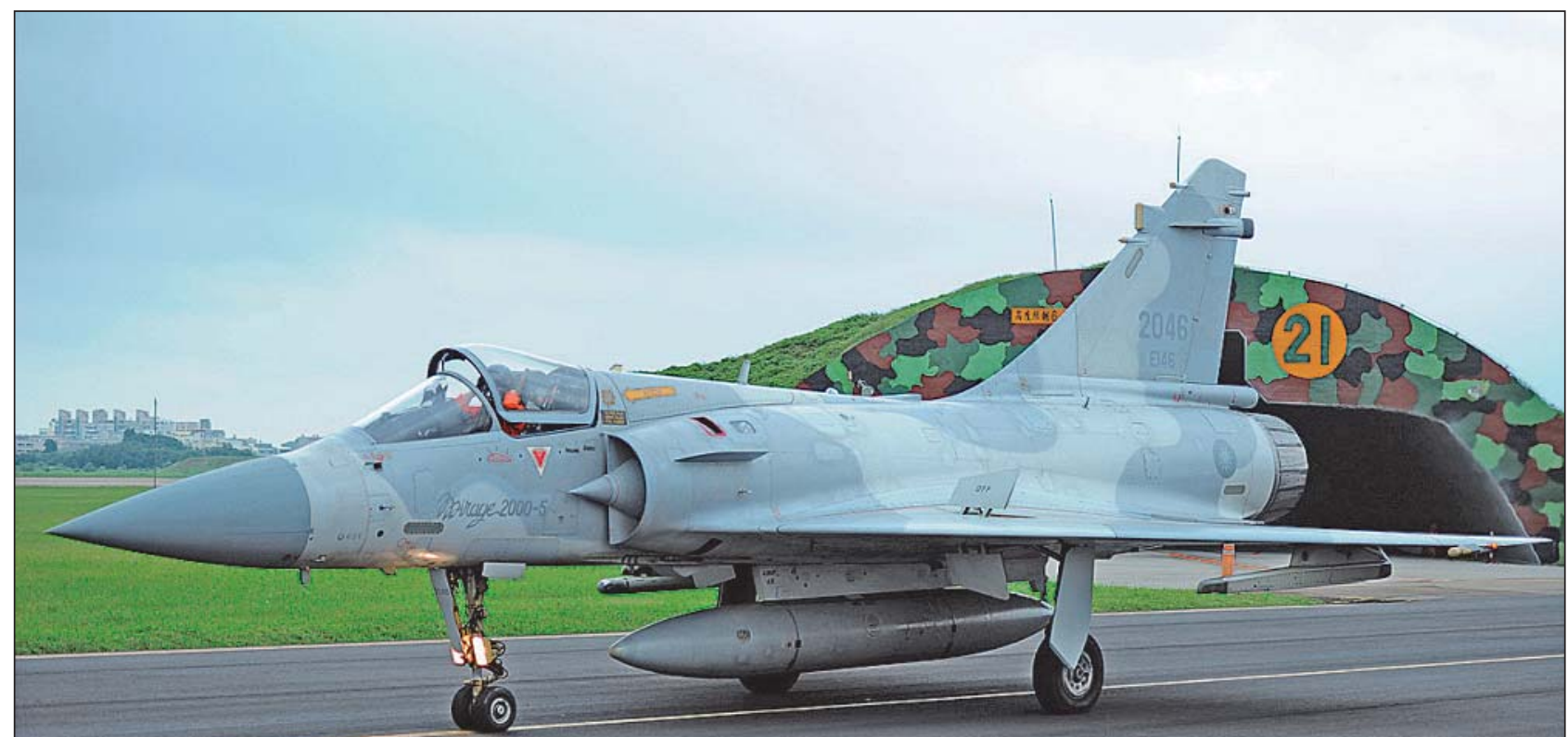


4. táblázat. A Mirage 2000-es típuscsalád veszteségei

\begin{tabular}{|l|c|c|c|}
\hline \multicolumn{1}{|c|}{ Ország } & $\begin{array}{c}\text { Rendszerbe } \\
\text { állítva (db) }\end{array}$ & $\begin{array}{c}\text { Vesz- } \\
\text { teség } \\
\text { (db) }\end{array}$ & $\begin{array}{c}\text { Vesz- } \\
\text { teség } \\
\text { arány [\%] }\end{array}$ \\
\hline Franciaország & 315 & 52 & 18,1 \\
\hline India & 59 & 11 & 18,6 \\
\hline Görögország & 55 & 15 & 27,3 \\
\hline Emirátusok & 68 & 5 & 7,4 \\
\hline Taiwan & 60 & 5 & 8,3 \\
\hline Egyiptom & 20 & 1 & 5,0 \\
\hline Katar & 12 & & \\
\hline Brazília & 12 & & \\
\hline Peru & 12 & & \\
\hline
\end{tabular}

\section{MIRAGE 2000-ES REPÜLŐGÉPEK NAPJANKBAN}

A rendszeresítő országok közül egyedül Brazília repülte ki a használt Chasseur változatokból a repülési időt, és vonta ki a repülőgépeket a hadrendből. Európában Franciaor- szág és Görögország is rendszerben tartja a Mirage 2000es változatokat. Franciaország 2015-ben még 120 darabot tartott hadrendben az AdLa kötelékében.

Európán túl, a Közel-Keleten Egyiptom, Katar és Egyesült Arab Emirátusok szintén rendszerben tartja a típust. Egyiptom egy százados repülőgépállománya (82. SQ. (تيرصحل ثبو جلا تاوقنال 18 db Mirage 2000 BM/EM repülőgépből áll. A katari sejkség százada (QATAR EMIRI AF (QEAF) • قيرطقل قُحلسملا تاوقلا SQ7.) 14 db Mirage 2005-5EDA/5DDA repülőgépből áll. Az Egyesült Arab Emirátusok két repülöbázisán három század repüli a DeuxMille repülőgépeket. $A$ régebbi Mirage 2000RAD,DAD és EAD változatokat modernizálták 2000-9EAD/DAD modifikácikókra, amelyek a legkorszerübbek a 2000-res repülőgép családban.

India régebbi Mirage $2000 \mathrm{H}$ (VAJRA) vadászgépeit, amelyek alapfokúan csapásmérésre képesek, 2000-5Mk2-re építi át. Az első repülőgépeket Franciaországban, a többit a hazai HAL repülőgépgyárban modernizálják.

A Kínai Köztársaság (Taiwan) három századát a Hsinchi légitámaszpont üzemeteti a 2. (régebben 499.) vadászrepülő-ezred állományában.

Peru egyetlen Mirage 2000-es százada (Escuarón Aéreo 412. Halcón) $9 \mathrm{db}$ Mirage 2000P/DP repülőgéppel a La Joya repülőtámaszponton állomásozik, közösen a 111. harci helikopterszázad orosz gyártású Mi-25D/35P harci helikopereivel.

5. táblázat. Franciaország által rendszerben tartott Mirage 2000-es változatok

\begin{tabular}{|l|l|c|}
\hline \multicolumn{1}{|c|}{ Század neve } & \multicolumn{1}{c|}{ Repülögépek típusa } & $\begin{array}{c}\text { Repülőgépek } \\
\text { száma (db) }\end{array}$ \\
\hline Escradron de chasse 01.001 Cigognes & Mirage 2000-5F & 25 \\
\hline Escradron de chasse 01.003 Navarre & Mirage 2000D & 18 \\
\hline Escradron de chasse 02.003 Champagne & Mirage 2000D & 20 \\
\hline Escradron de chasse 02.004 La Fayette & Mirage 2000N K3 & 31 \\
\hline Escradron de chasse 02.005 lle de France & Mirage 2000B/C & 31 \\
\hline Escradron de chasse 03.003 Ardennes & Mirage 2000D & 7 \\
\hline Escradron de chasse 03.011 Corse & Mirage 2000D/5F & 7 \\
\hline Escradron de chasse at d'expérimentation 05.330 Cote D'Argent & Mirage 2000C/D/5F & 3 \\
\hline Escradron de transformation Mirage 2000D 02/007 Argonne & Mirage 2000D & 3 \\
\hline Mirage 2000 összesen & & 145 \\
\hline
\end{tabular}

6. táblázat. A görög légierő Mirage 2000-es állománya 2015-ben

\begin{tabular}{|l|l|c|}
\hline \multicolumn{1}{|c|}{ Század neve } & \multicolumn{1}{|c|}{ Repülögépek típusa } & $\begin{array}{c}\text { Repülőgépek } \\
\text { száma (db) }\end{array}$ \\
\hline 331. Mira Theseus & Mirage 2000-5 Mk2 & 19 \\
\hline 332. Mira Falcon & Mirage 2000BGM/EGM3 & 25 \\
\hline
\end{tabular}

7. táblázat. Az Egyesült Arab Emirátusok légierejének Mirage 2000-es állománya

\begin{tabular}{|l|l|c|}
\hline \multicolumn{1}{|c|}{ Század neve } & \multicolumn{1}{c|}{ Repülőgépek típusa } & $\begin{array}{c}\text { Repülőgépek } \\
\text { száma (db) }\end{array}$ \\
\hline 71st Fighter Squadron & Mirage 2000-9EAD/DAD & 22 \\
\hline 76th Fighter Squadron & Mirage 2000-9EAD/DAD & 22 \\
\hline 86th Fighter Squadron & Mirage 2000-9EAD/DAD & 24 \\
\hline
\end{tabular}


8. táblázat. A India légierejének Mirage 2000-es állománya

\begin{tabular}{|l|l|c|}
\hline \multicolumn{1}{|c|}{ Század neve } & Repülögépek típusa & $\begin{array}{c}\text { Repülögépek } \\
\text { száma (db) }\end{array}$ \\
\hline 1. Fighter Squadron, Tigers & Mirage 2000-H/2000-5mk2 & 14 \\
\hline 7. Fighter Squadron, Battleaxe & Mirage 2000-H/2000-5mk2 & 14 \\
\hline $\begin{array}{l}\text { 9. Fighter Squadron, Wolfpack } \\
\text { Tactics and Combat Development and Training Establishment } \\
\text { =TACDE) }\end{array}$ & Mirage 2000-H/2000-5mk2 & 14 \\
\hline
\end{tabular}

9. táblázat. Taiwan légierejének Mirage 2000-es állománya

\begin{tabular}{|l|l|c|}
\hline \multicolumn{1}{|c|}{ Század neve } & Repülőgépek típusa & $\begin{array}{c}\text { Repülőgépek } \\
\text { száma (db) }\end{array}$ \\
\hline 41.Tactial FighterGroup & Mirage 2000-5El/2000-5DI & 18 \\
\hline 42. Tactial FighterGroup & Mirage 2000-5El/2000-5DI & 19 \\
\hline 48. Tactial FighterGroup & Mirage 2000-5El/2000-5DI & 19 \\
\hline
\end{tabular}

\section{ÖSSZEFOGLALÁs}

Összegezve megállapítható, hogy a Mirage 2000-es az utolsó deltaszárnyú harci repülőgép volt. Korai példányai még csak öt felfüggesztési ponttal rendelkeztek, ezért fegyverterhelésük és azok variációs lehetősége csekély volt. A gépek analóg műszerekkel rendelkeztek. A jó repülési tulajdonságuk mellett könnyű vezethetőség és kiváló elektronikai ellentevékenység rendszerek jellemezték a típust.

30 év alatt 601 darab sorozatgyártású repülőgépből - nem hivatalos adatok szerint - 89 darab zuhant le, ami közel a gépek 20\%-a. Évente 2-3 darab Mirage 2000-es katasztrófa történt. A görög légierő 27\%-át, India és Franciaország $18 \%$-át vesztette el a gépeinek. Az Egyesült Arab Emirátusok $7 \%$-os vesztesége ténylegesen $4 \%$ alatt van (68 gépből 5 darab), mivel két gépüket is Franciaországban vesztették el.

A francia légierő szinte minden feladatkörre alkalmassá tett változatokat rendelt, így a Mirage 2000Chasseur a vadász, a Nucléaire az atombombázó, a Diversifie az általános hagyományos támadógép szerepét töltötte be. Felderítésre a különféle felderítő konténerekkel volt alkalmas. A vadászváltozatból készítettek kétüléses példányokat, amelyek harci bevetésre is alkalmasak voltak, a csapásmérők tandemülésessel készültek. A Mirage 2000-5-ös és 2000-9-es gépek már minden harcfeladatra alkalmasak,

\section{0. ábra. Mirage 2000-es Peruban}

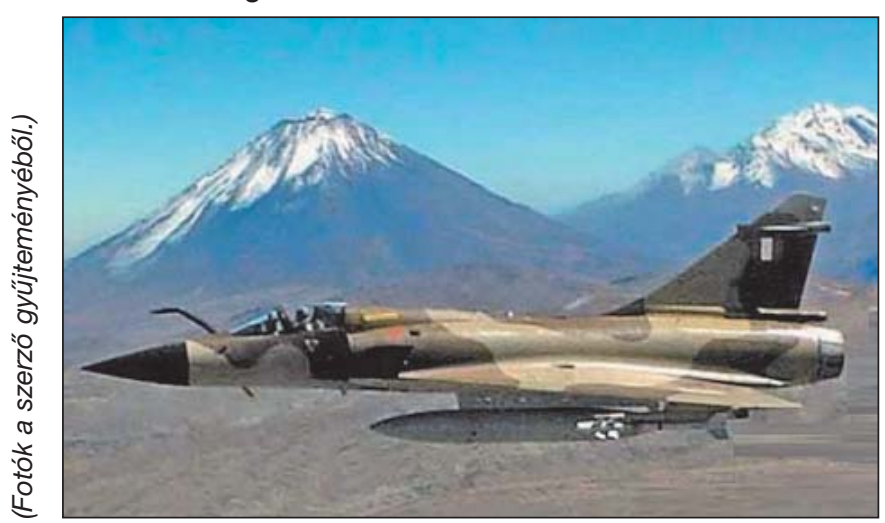

közel egyenértékűek az amerikai F-16-os, és F/A-18-as gépcsaláddal. A francia gépek hátránya a magas üzemeltetési költségeken kívül, a saját adatbuszok alkalmazása, amely megnehezíti más országok fegyverzetének integrációját és használatát. A gépek másik hiányossága az üzemanyag-rendszer robbanásbiztonságának elhanyagolása. Ez a svéd gépekkel azonos probléma. Érdekes módon, a nyilvánosságra hozott adatok alapján, az üzemeltetők Mirage 2000-est nem vesztettek el üzemanyag-robbanás következtében.

A Mirage 2000-9-es gyakorlatilag egyenértékű a többi 4++ generációs repülőgépekkel. Megfelelő karbantartás esetén üzembiztos és magas hadrafoghatóságú típus. A magas hadrafoghatóságnak és üzembiztosságnak azonban komoly ára van, mivel szupport és fenntarttási költsége meghaladja az amerikai F-16-osét. (Az új Rafale, az európai Eurofighter, illetve az F-15-ös költségei hasonlóan alakulnak mint a Mirage 2000-esé). A francia Dassault a Rafale kifejlesztése után, a Mirage 2000-es további modernizálása helyett, az új típust ajánlja a potenciális vásárolóknak. A francia állam szűkős forrásai nem teszik lehetővé a légierőnek a Mirage 2000-es nagymértékű korszerűsítését, így azokat nem építik át a 2000-9-es modifikációra, hanem a Dassault Rafale gépek gyártásának függvényében, inkább lassan kivonják őket a szolgálatból. Ennek ellenére, a Mirage 2000-es harci gépek még 2030 után is valószínűleg rendszerben lesznek a világ több légierejénél.

\section{FoRRÁSOK}

http://www.vectorsite.net/avmir2k.html;

http://htka.hu/2009/02/21/dassault-mirage-2000/;

http://www.mirage-jet.com/index.html;

http://www.ejection-history.org.uk/Aircraft_by_Type/

Mirage_2000/mirage_2000.htm;

David Donald: „Dassault Mirage 2000” The Complete Encyclopedia of World Aircraft. Barnes@Noble Books

1997. ISBN 0-7607-0592-5;

Gerald Frawley "Dassault Mirage 2000" The International Directory of Military Aircraft 2002/2003 Fishwick, Act:

Aerospace Publications, 2002. ISBN 1-875671-55-2;

Air Cosmos/Aviation Magazine No 1400 Semainde du 16

AU 22 Novembre 1922: Le Mirage 2000-5 Face Au F-16. 